Non-specialist Teachers' Confidence to Teach PE: The Nature and Influence of Personal School Experiences in PE

Author(s): $\quad$ Dr Philip Morgan and Prof. Sid Bourke

E-mail:

Philip.Morgan@newcastle.edu.au

Institutional Affiliation: School of Education

Faculty of Education \& Arts

University of Newcastle

Callaghan, NSW, 2308, Australia.

Date of Submission: $\quad 6^{\text {th }}$ February, 2006.

Professional Profile: Dr Philip Morgan is a Lecturer in the School of Education at the University of Newcastle.

Professor Sid Bourke is a Professor of Education and Assistant Dean (Research \& Research Training) at the University of Newcastle. 


\section{Non-specialist Teachers' Confidence to Teach PE: The Nature and Influence of Personal School Experiences in PE}

Background: Over the past 20 years, a number of researchers have expressed concern over the lack of confidence and qualifications of primary school teachers to teach PE. Evidently, the influence of personal school PE experiences may play an important role in the development of teachers' confidence to appropriately teach PE. Most research that has examined the effects of biographical experiences in PE on teachers' confidence teaching PE has focused on specialist, rather than non-specialist PE teachers.

Purpose: Two major aims of this study were (i) to examine the nature of personal school experiences of non-specialist student and inservice primary teachers and, importantly, the influence of these experiences on their PE teaching confidence and (ii) to analyse the reasons provided by teachers to explain their level of PE teaching confidence. No studies to date have attempted to test a theoretical causal model of this nature using $\mathrm{PE}$ teaching confidence as the key dependent variable and personal school experiences in PE as mediating variables.

Participants and Setting: Quantitative data were collected from non-specialist student teachers in years 2, 3 and 4 of preservice education $(n=386)$ and inservice $(n=53)$ primary teachers in New South Wales (NSW), Australia. The student teacher sample consisted of students studying a double degree majoring in primary education in the second $(n=143)$, third $(n=127)$, or fourth year $(n=116)$ of their higher education at a NSW tertiary institution. Inservice teachers were randomly selected from NSW primary schools from both the state school system and non-state school system. In total, 53 inservice teachers were included from 37 different schools.

Research Design: Employed a non-experimental correlational research design with Confidence Teaching PE as the key dependent variable.

Data Collection: Largely quantitative data was collected via the administration of a questionnaire which utilised both select-response and open-ended questions.

Data Analysis: One-factor congeneric measurement models were utilised in this study to produce estimates of constructs for primary and secondary school PE experiences and commitment to sport and physical activity. Self-perceived levels of confidence were also assessed in the teaching of ten PE content areas. Hypothesised relationships between key variables were tested using multilevel structural equation modelling techniques.

Findings: Many respondents' PE experiences included programs that lacked variety and frequency of delivery, were dominated by involvement in 'supervised' games and involved little teaching and learning. Individuals who recalled more negative experiences in school PE were less likely to be involved in physical activity and indicated lower levels of PE teaching confidence than those who had more favourable experiences. Respondents held only a 'moderate' level of confidence in their PE teaching abilities. Results indicated that the quality of an individual's school PE experiences directly predicted his or her confidence to teach PE (variance explained $=30 \%$ ). It was apparent that many of the reasons provided for a lack of confidence were based on memories of poor quality school PE.

Conclusions/Recommendations: To prevent the perpetuation of a non-teaching ideology or the decision by many teachers to avoid teaching PE, teacher educators must look to incorporate biographical analysis (including reflection sessions, group work, values clarification activities, portfolios) and opportunities for PE teaching as part of preservice courses. Teacher educators may need to make students become dissatisfied and disgruntled with perpetuating their previous negative or non-teaching experiences, providing them with more appropriate conceptions. Teacher educators may use this information to design more relevant courses incorporating meaningful learning experiences. Strategies employed at the tertiary level, such as increased opportunities to improve mastery expectations, should be complemented with relevant and purposeful professional development for all classroom teachers. 


\section{Introduction}

Primary school physical education (PE) can make a unique contribution to the educational experience of students and may support physical, cognitive, emotional and social development. However, it has been reported over a number of years that many PE programs in primary schools are of poor quality (Hardman \& Marshall, 2001; Senate Standing Committee on Environment, Recreation and the Arts [SSCERA], 1992), as a significant number of classroom or non-specialist teachers have difficulty teaching PE. Some of the major barriers to effective teaching in PE include inadequate training, a lack of time and interest, limited support and resources, and low levels of teacher confidence (DeCorby, Halas, Dixon, Wintrup \& Janzen, 2005; Curtner-Smith, 1999; Graham, 1991; Morgan \& Bourke, 2005).

Over the past 20 years, a number of researchers in Australia have expressed concern over the lack of confidence and qualifications of classroom teachers to teach PE. Notably, it was generally acknowledged that the lack of success of the 'Daily PE Program' introduced in Australian primary schools over two decades ago was attributed to a lack of knowledge and confidence of classroom teachers. In a comprehensive review and critique of Daily PE, Kirk (1989) explained how the quality of Daily PE lessons had reduced significantly as a result of poor teacher practice. Kirk, Colquhoun and Gore (1988) found that classroom teachers did not possess the skills or knowledge needed to deliver adequate PE lessons. Tinning and Hawkins (1988) described how PE lessons had become supervised 'fitness sessions' and teachers had stopped teaching skills.

A Senate Inquiry into Physical and Sport Education in 1992 documented the problems with PE teaching in Australian primary schools citing a lack of confidence and qualifications of classroom teachers as key inhibiting factors (SSCERA, 1992). Several recommendations to improve the quality of programs were outlined. However, despite this comprehensive evaluative report, several Australian studies have since provided evidence that the situation has not improved and that many classroom teachers lack the qualifications to deliver PE programs and have experienced inadequate teacher training in PE (Moore, Webb, \& Dickson, 1997; Morgan \& Bourke, 2005; Thompson, 1996; Walkley, 1992; Webb, Moore, Gray, \& Jessup, 1993). 
Not surprisingly, a significant majority of non-specialist teachers are critical of their PE teacher training (DeCorby et al., 2005; MacKendrick, 1996; Morgan \& Bourke, 2005; Thompson, 1996). Recently, Morgan and Bourke (2005) found that classroom teachers believe they require more extensive teacher training in PE delivered through longer courses with greater exposure to PE teaching. Morgan and Bourke (2005) found a strong relationship between teachers' training in PE and their perceived confidence to teach PE. Teachers felt significantly less confident to teach those PE content areas for which they perceived they had received poorer quality training. In a study examining the perceptions of preservice non-specialist teachers in PE, Moore et al. (1997) concluded that many university courses for teachers are not effective in developing the necessary confidence to adequately teach PE.

Other studies have offered explanations for teachers' low levels of confidence. Xiang, Lowy and McBride (2002) found that many classroom teachers believed they did not possess the knowledge or ability to teach PE after observing a number of PE lessons. Moreover, Carney and Chedzoy (1998) asserted that the lack of confidence non-specialists have for teaching PE is related to a lack of belief in their own ability to perform skills and activities competently.

However, despite evidence that non-specialists lack confidence teaching PE, it has been reported they generally believe that PE is a valuable component of the curriculum (DeCorby et al., 2005; Morgan \& Bourke, 2004). Morgan and Bourke (2004) found that non-specialists believed in the benefits of PE but would generally prefer to teach other subjects rather than PE due to a perceived lack of knowledge and ability in this key learning area. DeCorby et al. (2005) also found that teachers' believed in the value of PE. However, the authors explained that these positive perceptions did not guarantee the delivery of quality PE or that students develop desired knowledge and skills.

The Importance of Examining Personal School PE Experiences

Overall, this study is based on an understanding that the experiences or personal backgrounds of teachers are important components affecting the teaching and learning process. This understanding acknowledges the relevance of Bandura's $(1977,1986)$ theory of social learning. As Bandura (1977) noted, it is through life 
experiences that individuals develop a general expectancy about action-outcome contingencies and a belief about their own coping abilities, confidence or self-efficacy. That is, the theory of social learning assumes that a person's ability to cope with a specific situation is a result of his or her experiences. His or her experiences help develop images about a specific situation and have been referred to as 'sources of information.' Sources of information are cognitively processed to determine levels of efficacy and ultimately behaviour.

Adapting this theory to the context of Australian primary schools highlights the significance of exploring personal school experiences in PE. Primary school PE is often taught infrequently, with programming decisions left to the discretion of the classroom teacher. Furthermore, many preservice teachers may complete their teacher training without having taught PE (see ACHPER Teacher Training Working Party [1997] as an indicative reference of this assertion). Acknowledging these realities, it is reasonable to suggest that classroom teachers may have minimal or no source(s) of information concerning their ability to teach PE and may have to cognitively process and rely on images formed about PE teaching through their personal school experiences. Overall, the perception of the difficulties in teaching PE and ultimately teaching confidence reflects past experiences in PE (teaching or as a student) and anticipated impediments.

The influence of personal school PE experiences may play an important role in the development of attitudes and perceived competencies regarding PE teaching as the major, or in some cases, the only source of information teachers have about PE. This may ultimately reflect their confidence to appropriately teach PE. The potential negative consequences of this proposition need to be recognised. For those teachers with negative memories of school PE, the thought of teaching a subject that was not enjoyed may be a substantial barrier to effective teaching and adversely impact on teachers' PE teaching confidence and their subsequent teaching behaviour. It is important to acknowledge that similar associations between experiences and teaching confidence have been researched in other key learning areas of the primary curriculum. Using regression analysis, Jarrett (1999) established a link between personal school experiences in science and current interest and confidence in science of elementary teachers. The Senate Environment, Recreation, Communications and the Arts Reference Committee (1995) emphasised that classroom teachers lack confidence to teach art because of their own poor art experience at school and inadequate teacher training 
resulting in a strong impulse to marginalise art in their teaching programs. Russell-Bowie, McInerney, and Yeung (2001) reported relationships of this nature in a study focusing on music education in primary schools.

Many researchers have indicated that personal school experiences in PE provide prospective teachers with a wide range of information about PE, which may potentially affect attitudes, beliefs, and teaching practices (Belka, Lawson, \& Cross-Lipnickey, 1991; Doolittle, Dodds, \& Placek, 1993; Keating, Silverman, \& Kulinna, 2002; Lawson, 1983b; Placek et al., 1995). Teacher socialisation theory describes the socialisation of teachers as a life-long process (Lawson, 1983a), beginning at school and continuing into their professional years as teachers. The notion that people are socialised into choosing a specific profession has previously been an area of interest in research on PE specialists (Dewar \& Lawson, 1984; Lawson, 1983a, 1983b, 1986; Locke, 1984; Placek \& Dodds, 1988). Crum (1990) provided a description of teacher socialisation theory in a PE context, which clearly link, with social learning theory, by highlighting the significance of prior experiences:

It is generally accepted that prospective physical educators do not bring tabula rasa to formal professional training programs, but that their anticipatory professional conceptions are shaped by experiences obtained in physical education classes and in participation in exercise, play, and sport outside the school context (p. 287).

Essentially, positive and negative experiences in school PE may affect the development of beliefs throughout primary school, high school, university, and early teaching life. Research has described the effects of biographical experiences in sport on teachers' beliefs and confidence about teaching PE. However, most research in this area has focused on specialist, rather than non-specialist PE teachers. Of the limited studies examining personal school experiences in PE of non-specialists, there is a general agreement that they have poor memories of PE, which more often than not, combine into a negative outcome (Allison, Pissanos, \& Sakola, 1990; Clayton, 1999; Howarth, 1987; Portman, 1996). A small amount of studies have focused on preservice teachers' experiences. Portman (1996) found that preservice elementary education majors had strong views about their PE experiences and many were not interested in repeating bad experiences and embarrassing situations they remembered. Allison et al. (1990) found that student teachers possessed both positive and negative memories of school PE and that their elementary teachers of PE (specialist teachers for $81 \%$ of the sample), played a significant role in shaping their beliefs about PE. 
Few studies have attempted to examine the relationship between personal school experiences in PE of nonspecialist preservice teachers and their perceptions of PE. In a study of British primary preservice teachers, Carney and Chedzoy (1998) reported that subjects with negative prior experiences held such strong beliefs about their abilities that it affected their learning at university. One particular student, despite a positive experience in gymnastics at university, rejected what he had learned and still perceived gymnastics as threatening as a result of a negative experience in gymnastics at school. The researchers concluded, "if a student had an interest in an area and had positive prior experiences of an activity, he or she was more likely to be committed to that area” (p.32). Furthermore, some indication of an association was provided qualitatively by Chedzoy (2000) and Kirk et al. (1988). However, the main purpose of the study by Chedzoy was to examine the influence of enrolment in a one-year Postgraduate Certificate of Education Course on perceived teaching competence of 24 students. Overall, more research is needed to examine the nature of personal school experiences of non-specialist preservice and inservice teachers and, importantly, the influence of these experiences on their PE teaching confidence.

\section{Purpose of the Study}

In general, research on PE teacher education and teaching in PE has focused on specialist rather than nonspecialist teachers. There is currently a paucity of research examining issues relating to PE teaching and preservice non-specialists in PE. Given the substantial influence a teacher may have on the achievement of student outcomes, this study focused on both prospective and practising teachers of primary school PE. It is suggested that the quality of PE programs delivered in the primary school is associated with a teacher's perceived confidence to teach PE. The logical assumption is that more favourable levels of outcome attainment will be realised by students if they experience lessons implemented by competent and confident teachers who are committed to teaching PE. Two major aims of this study were (i) to examine the influence of theoretically substantiated variables on a teacher's perceived confidence to teach PE by testing a developed theoretical causal model and (ii) to analyse the reasons provided by teachers to explain their level of PE teaching confidence. No studies to date have attempted to test a theoretical causal model of this nature using PE teaching confidence as the key outcome or dependent variable and personal school experiences in $\mathrm{PE}$ as mediating variables. The key research questions were: 
1. What was the nature of personal school experiences in PE of teachers?

2. Did personal school experiences in PE influence perceived competence to teach PE?

3. How did perceived confidence vary between preservice and inservice teachers?

4. What were the major reasons provided for and against feeling confident and competent teaching PE?

\section{Method}

\section{Participants}

Data were collected from 386 preservice and 53 inservice teachers in New South Wales (NSW), Australia. The preservice teacher sample consisted of students studying a double degree (Bachelor of Arts/Bachelor of Teaching), majoring in primary education in the second $(n=143)$, third $(n=127)$, or fourth year $(n=116)$ of their higher education at a NSW tertiary institution. The four-year integrated degree prepares students for teaching in the primary school. Students enrol in two PE courses as part of their training. In $2^{\text {nd }}$ Year, students attend a one-hour mass lecture and a one-hour tutorial per week for seven weeks. In $3^{\text {rd }}$ Year, a onehour mass lecture and a two-hour tutorial is undertaken each week over nine weeks. Students participate in activities from the four PE content strands of the K-6 syllabus; Games and Sports, Gymnastics, Dance, and Active Lifestyle. All students from each year group were invited to be respondents. Response rates for all cohorts were over 80 percent. Inservice teachers were randomly selected from NSW primary schools from both the state school system and non-state school system. In total, 53 inservice teachers were included from 37 different schools.

\section{Data Collection Procedures}

Largely quantitative data were collected from all respondents by the administration of a questionnaire which utilised both select-response and open-ended questions. Second Year students completed the questionnaire prior to completing any practicum teaching and before they had undertaken any teacher training in PE. Third year students completed the questionnaire immediately following completion of their compulsory PE teacher training and had experienced at least a two-week block practicum. The $4^{\text {th }}$ Year students completed their questionnaire at the end of their last practicum experience at University. The $4^{\text {th }}$ Year students had completed 
three different length practicums (2 weeks, 4 weeks, \& 8 weeks of a 10-week internship). All inservice teachers were asked to respond to a mailed questionnaire.

\section{The Development of a Causal Model}

The causal model presented in the current study was based on extensive research, time precedence and substantive theory considerations. Causal models are generally developed preceding the utilisation of structural equation modelling techniques, which assist the identification of relationships to be tested (Anderson \& Gerbing, 1988; Bollen \& Long, 1993: 2). Structural modelling techniques do not determine the direction of causality between latent variables or conclude that a causal relationship exists (Arnold, 1992; Goldstein, 1995: 12; Haag, 1992). Rather, the purpose of data analysis is to identify variables that predict other variables (Arnold, 1992) and to ascertain whether the theoretical model is consistent with the data (Bollen, 1989: 38). If the data are consistent with the model, this does not represent proof of a theory, it at best lends support to it (Pedhazur, 1997: 768-769). That is, data do not confirm a model, they only fail to disconfirm (Anderson \& Gerbing, 1988; Bollen, 1989: 79; Cliff, 1983; Haag, 1992).

A two-stage process was used in this investigation to examine causal relationships and incorporated both LISREL8 measurement models and multilevel analysis using MLwiN. The first stage involved the use of LISREL8 (Jöreskog \& Sörbom, 1993) to develop one-factor congeneric measurement models to supply proportionally weighted composites from multiple indicators of latent constructs under restricted sample size conditions. LISREL8 enables the analysis of causal hypotheses of covariance structural models on the basis of non-experimental data. The modelling procedure originates from an acknowledgment that many social and behavioural processes act as causal processes, which function among latent variables (Pang, 1996). The second stage used the developed constructs in the multilevel analysis program, MLwiN (Rasbash et al., 2000), to determine the significance of individual and cohort effects. 


\section{Construct Development}

One-factor congeneric measurement models were utilised in this study to produce estimates of constructs for primary and secondary school PE experiences and commitment to sport and physical activity. Table 1 displays information for all multivariate constructs developed in this study. For each construct, detail is provided about the initial factors or source of the scale, the major elements relating to the construct, item examples, and statistical information including goodness-of-fit measures and construct reliabilities. The use of fit statistics ensured the indicators validly contributed to the latent construct being estimated. Several indices are displayed in Table 1, which examined goodness-of-fit in this study and indicated how well the models accounted for the data. Many researchers have listed the merits of the use of multiple indexes, which represent incremental and absolute fit measures when assessing model fit (Hair, Anderson, Tatham \& Black, 1995: 661-662; Hu \& Bentler, 1995; Kelloway, 1998: 26; Lavee, 1988; Loehlin, 1992: 57). All fit statistics passed the criteria considered acceptable for all composite scales. Generally, fit index values greater than 0.90 and RMSEA values less than 0.05 were accepted as an adequate fit. All reliabilities were high (ranging from 0.868 to 0.896 ), with the exception of the Quality of Primary PE Program construct (0.608).

\section{Insert Table 1}

Self-perceived levels of confidence were assessed in the teaching of ten PE content areas; Major Games, Gymnastics, Athletics, Dance, Aquatics, Fitness, AUSSIE SPORT, Adapted PE, Outdoor Education and Motor Skills. These content areas were selected as they were representative of the practical content areas of the K-6 PE syllabus that teachers in the study were required to teach. Respondents were asked to grade their level of competence and confidence in each content area on a six-point Likert scale by responding to the statement: 'If I were to teach PE, I would feel confident and competent teaching...'. Additionally, respondents were asked to provide reasons for their levels of competence and confidence. 


\section{Results}

Table 2 displays the correlation matrix for all variables to be used in the causal model, along with relevant descriptive statistics. A discussion of the findings for each variable will be included in the multilevel model examination. The relationships highlighted in Table 2 will also be discussed in more detail upon consideration of multilevel effects. Several strong relationships existed between and within school experience variables and the confidence teaching PE variable.

\section{Insert Table 2}

\section{Applying the Multilevel Model}

It is important to acknowledge that data collected from educational institutions often have a nested structure as a result of different levels of structures found within these systems (Arnold, 1992; Draper, 1995; Hox, 1995; Li, Duncan, Harmer, Acock, \& Stoolmiller, 1988; Osborne, 2000). Hierarchical linear models involve predicting the characteristics of individuals who are nested within groups that may be nested within other groups, inside a larger group (Arnold, 1992; Bryk \& Raudenbush, 1992: 4; Osborne, 2000). By considering the hierarchical nature of the data, multilevel modelling takes into account clustering effects and assists the understanding of where and how effects occur (Arnold, 1992; Draper, 1995; Rasbash et al., 2000: 8). For example, students who attend universities learn in year groups or, as it will be referred to in this study, cohorts. Individuals within cohorts tend to be more alike than individuals selected at random and both the cohorts and individuals have qualities at their respective levels of observation (Arnold, 1992; Hox, 1995: 6; Li et al., 1998; Osborne, 2000).

The hierarchical linear model has been widely used in general educational research but very rarely by researchers of PE and exercise science. Previously, Zhu (1997) claimed that although many data are clustered within multilevel structures, the structures have been ignored in data analysis for a long time and are rarely acknowledged by academics in PE, exercise, and sport. Many studies in PE research incorrectly select analytical models of multilevel data due to confusion about units of analysis (Zhu, 1997). This can 
lead to seriously biased results and possibly invalid conclusions such as the ecological fallacy where grouplevel data is utilised to make conclusions about individuals (Hox, 1995: 5). Multilevel analyses enable the researcher the opportunity to obtain statistically efficient estimates of regression coefficients and accurate standard errors, confidence intervals, and significance tests (Goldstein, 1995: 3).

\section{The Fitted Multilevel Model}

This study was concerned with a hierarchical structure at only two levels; individuals at level 1 and cohorts at level 2. A cohort described the four level-2 groups; $2^{\text {nd }}$ Year $(n=143), 3^{\text {rd }}$ Year $(n=127)$, and $4^{\text {th }}$ Year $(n=116)$ preservice teachers and inservice teachers $\left(n=53\right.$, coded as $5^{\text {th }}$ Yr). The explanatory model hypothesises the ordering of the assumed cause-and-effect relationships (refer to Figure 1). The pattern of causation moves from higher-level units to lower-level units and from left to right, meaning the outcome variable, confidence teaching PE, is potentially influenced by all variables to the left. The model has been developed so that variables included are potentially influenced by all prior variables. That is, previous events influence subsequent events and variables may be directly or indirectly related to each other. The total size of effects is calculated as the sum of the direct effects and the indirect effects operating through mediating variables.

\section{Insert Figure 1}

The constructs developed in this study were used in multilevel models to explore possible cohort effects. The multilevel analysis program MLwiN (Rasbash et al., 2000) was used to establish standardised coefficients at the five percent significance level appropriate for a two-tailed test. The numbers shown on the paths in all models are standardised path coefficients $(\beta)$. Standardised regression coefficients enable the direct comparison of the strength of a relationship for each explanatory variable (Hox, 1995: 25) and represented effect size. Figure 1 highlights all of the significant direct fixed effects of the full standardised model for the 439 non-specialists. The sizes of the effects shown range from $\beta=0.15$ to $\beta=0.68$. The various sub-models explained between 29 percent and 46 percent of the total variance for each respective response variable. The five key variables of this study were examined as response variables. The results are displayed in Table 3. 


\section{Insert Table 3}

\section{Gender and Age}

The sample consisted mainly of females (approximately 85\%) which is representative of the female gender bias inherent in Australian primary schools (Smith, 1999). Most respondents were less than 30 years old due to the large number of preservice teachers in the sample. It is not feasible to suggest that any variables could affect the background variables Gender and Age and therefore no explanatory variables were added to the Gender and Age null models.

\section{Personal School Experiences in PE}

The most common response for the frequency of PE lessons at primary school was 'at least once a week' (69.8\%). The majority of respondents were taught PE by their classroom teacher (82.1\%). Of the 575 respondents who listed the activity they spent most time participating in, 63.8 percent answered major games. Gymnastics (2.8\%), aquatics (2.6\%), and outdoor education (no responses) were among a group of activities with very low percentages. Interestingly, respondents indicated they had a 'moderately-positive' perception of the quality of their primary PE program and of their level of outcome attainment in primary school PE. The background variables Gender and Age were not significantly related to the Quality of Primary PE Program construct. The quality of an individual's primary school PE program was a significant variable for the Outcome Attainment in Primary PE construct registering a large regression coefficient $(\beta=$ 0.526), controlling for Gender and Age. Additionally, Gender was found to be a significant explanatory variable.

Of the 606 respondents who listed an activity they spent most time participating in secondary school PE, 76.4 percent answered major games, and this was overwhelmingly greater than any other activity. Athletics was the second most frequently listed (6.9\%) and all other activities recorded values less than 6 percent. Respondents rated their experiences in secondary school PE as average and lower than the scores reported for primary school PE. Outcome Attainment in Primary PE was found to be significant in the final form of 
the fitted Experience in Secondary PE model, recording a large regression coefficient ( $\beta=0.68)$, implying a very strong relationship.

Commitment to Sport and Physical Activity

The Commitment to Sport and Physical Activity construct did not have a natural metric, as it was a composite made up of other scales. Respondents indicated an average level of commitment to sport and physical activity. The final form of the fitted model included Gender, Age, Outcome Attainment in Primary PE, and Experience in Secondary PE. Although the direct effect of Outcome Attainment in Primary PE on Commitment to Sport and Physical Activity was 0.244, there was also an indirect path mediated through secondary school PE $(\beta=0.238)$. Similarly, the quality of an individual's primary school PE program did not have a significant direct effect on Commitment to Sport and Physical Activity. However, effects were mediated through Outcome Attainment in Primary PE and Experience in Secondary PE to register an indirect effect of 0.253. Overall, the effect of Outcome Attainment in Primary PE on Commitment to Sport and Physical Activity accumulated to a large total effect of 0.482 . The total effect of Gender on Commitment to Sport and Physical Activity was also increased via addition of indirect effects. The Outcome Attainment in Primary School PE construct mediated the effects of Gender $(\beta=-0.076)$. The negative coefficient indicated that males scored more highly on this construct.

\section{Confidence Teaching PE}

Respondents held only a 'moderate' level of confidence in their PE teaching abilities. At the individual-level, significant explanatory variables included Commitment to Sport and Physical Activity, Experience in Secondary PE, and Age. After entering cohorts as dummy variables, $2^{\text {nd }}$ Year preservice teachers were found to be less confident than other cohorts as they were the only cohort level found to be significantly different. Respondents were asked to indicate their level of concern regarding safety when teaching PE by reporting whether they had no safety concerns, were anxious with certain activities, or anxious with most activities. Approximately 73 percent of inservice and 79 percent of preservice teachers were at least anxious with some activities. 
Respondents were also asked to list the specific PE content area(s) they preferred not to teach. Of all responses to this question, 56.1 percent indicated gymnastics was the PE subject they would least prefer to teach. Other PE subjects noted were aquatics (26.6\%), major games (7.4\%), dance (4.6\%), outdoor education (2.7\%) and athletics (2.5\%). An examination of themes extracted from open-ended responses for the 'least preferred subject' question provided potential explanations as to why gymnastics was disliked. Most respondents suggested that safety issues were the leading concern about gymnastics teaching:

Too many things can go wrong - I have a low understanding of gymnastics and I worry about injury during gymnastics. (Female ${ }^{41}, 4^{\text {th }} \mathrm{Yr}$ )

Upon listing gymnastics as the content area they least preferred, a number of respondents explained their choice via examples of advanced gymnastics skills that are not part of the primary gymnastics curriculum:

Gymnastics, I cannot perform or teach things such as backflips and handsprings. I would be worried about demonstration and injury. (Female ${ }^{22}$, Inservice)

\section{Explanations for Level of Confidence Teaching PE}

Respondents were asked to indicate the reasons why they agreed or disagreed with the statement "If I were to teach PE, I would feel confident and competent teaching...” with regard to particular PE content areas. Three inter-related factors emerged and open-ended responses were grouped accordingly: Personal Experience and Knowledge (approx. 60\% of responses), Interest and Enjoyment (approx. 20\%) and Qualifications (approx. 20\%). Examples are now provided.

Many respondents felt confident to teach certain PE content areas as a result of prior experiences in the particular activity. Responses generally indicated that experience was gained through school, university, and sports involvement or any combination of these. Many of the respondents outlined that extensive experiences in various physical activities helped them to feel confident and competent about teaching PE:

I've had lots of experience in these sports and have been playing sport since a young age. (Female ${ }^{13}, 3^{\text {rd }}$ Yr) 
And:

Because I have not participated in these areas and therefore do not feel confident. (Female ${ }^{2}$, $4^{\text {th }}$ Yr)

Additionally, many respondents associated their prior experiences with a high level of personal sporting ability, which was recognised as a major factor for feeling confident and competent to teach PE:

Because I feel I am a competent performer in these activities, therefore I feel I can teach others about them competently. (Female ${ }^{112}, 2^{\text {nd }} \mathrm{Yr}$ )

And:

I have very poor skills in these activities. My co-ordination is poor and therefore am not confident teaching them. I couldn't demonstrate, so couldn't teach effectively. (Female ${ }^{86}, 3^{\text {rd }}$ Yr)

Some respondents felt very strongly about the quality of their school PE experience, given their low levels of self-perceived ability in sport:

I believe that aspects of school PE (gymnastics, aquatics, athletics, dance, and fitness) should be totally outlawed. They promote discrimination of less abled students by teachers and other better skilled students. Focusing on the body and not the mind is crap. (Male ${ }^{67}, 2^{\text {nd }}$ Yr)

A number of respondents associated perceived confidence levels of personal interest or enjoyment in particular content areas:

I enjoy these things myself and therefore would be able to teach them and be enthusiastic about teaching. (Female ${ }^{91}, 2^{\text {nd }}$ Yr)

And:

I do not like these activities and have never liked them and therefore I do not feel competent in them. (Female ${ }^{103}, 2^{\text {nd }} \mathrm{Yr}$ )

Many respondents associated perceived confidence with personal qualifications they obtained throughout university or other external means:

Throughout my university experience, I gathered some great skills and games and it motivated me to look for more. (Female ${ }^{16}, 4^{\text {th }} \mathrm{Yr}$ ) 
And:

I feel that they are specialist skills that have the potential for injury if not taught correctly and I am not trained in these. (Female ${ }^{32}$, Ins.)

\section{Discussion}

\section{Memories of Primary and Secondary School PE}

Most respondents tended to only 'agree slightly' with positively worded statements regarding the existence of key elements of their PE programs (for example, teaching quality, frequency of lessons, and variety of activities offered). Respondents indicated they achieved a 'moderate' level of outcome attainment in primary PE, although many believed their lessons resembled sport, based on a non-teaching ideology. Respondents rated their secondary PE experience lower than their primary PE experience. Males perceived their overall school PE experiences to be more positive, rating their skill and enjoyment level and involvement in physical activity significantly higher than females. Overall, the majority of respondents were involved in PE programs dominated by major games, where little 'teaching and learning' took place. Aquatics and gymnastics were the least taught activities. Placek et al. (1995) also reported that most preservice teachers remembered a PE program that focused on traditional team sports and games.

It is of relevance to note that respondents who were involved in PE lessons, with limited variety, that focused on sports rather than skills, and rated the quality of teaching as low, were more likely to indicate low levels of outcome attainment in primary PE. Poor quality primary PE programs did not enable students an opportunity for success, enjoyment, and physical activity. It was clear from these findings that the less favourable the level of outcome attainment in primary PE, the greater the chance for a negative experience in secondary school PE.

The Influence of Personal School Experiences in PE on Involvement in Physical Activity

A number of researchers have discussed the association between personal school PE experiences and involvement in physical activities. Past PE experience is important in terms of developing motor skills to 
enable enjoyable physical activity experiences (see for example Macfadyen, 1999 \& Sallis, Prochaska, Taylor, Hill, \& Geraci, 1999). Consistent with hypothesised relationships, significant and large direct and indirect effects linked personal school PE experiences constructs and Commitment to Sport and Physical Activity. Moreover, the influence of Outcome Attainment in Primary PE was substantially strengthened upon consideration of indirect effects, highlighting the importance of primary school PE. Motor skill learning theorists recognise the primary school years as the optimal time for skill learning due to the fact that motor skill learning curves climb exponentially. This area of research advocates that the learning of basic motor skills provide the foundation for future participation in many physical activities. Students who had received frequent, quality PE at school and whose PE experiences had seen them active, learn skills and have fun, tended to be more involved in sports and physical activity both throughout school and currently. The results of the current study reinforce the importance of experiencing success and enjoyment in primary PE for current and future participation in sport.

Additionally, males were more committed to sport and physical activity than females. The magnitude of this association was strengthened after considering the effects of Gender operating through the personal school PE constructs. Younger individuals were more committed to sport and physical activity than older individuals.

The Influence of Personal School Experiences in PE on Perceived Confidence Teaching PE

In general, most respondents indicated a 'moderate' level of PE teaching confidence. Indirect effects indicated that males tended to score more highly on the perceived confidence teaching constructs than females, as males were more involved in sporting activities and remembered their school PE experiences more favourably than females. Younger respondents were also more confident in their ability to teach a number of PE content areas. The negative influence of Age on teaching confidence in PE has been previously reported by Thompson (1996).

Individuals who were less committed to sport and physical activity reported less positive experiences in school PE and felt less confident and competent in their ability to teach various PE content areas effectively. 
Carney and Chedzoy (1998) also found a relationship between experiences in sport and self-efficacy in PE teaching. Rolfe (2001) discussed the importance of prior experiences as a factor affecting non-specialist preservice teachers' confidence to teach dance.

A teacher education effect remains a plausible explanation for the significant pathway from the $2^{\text {nd }}$ Year cohort to the Confidence Teaching PE variable. Second Year preservice teachers tended to record lower scores than all other cohorts, probably as they have not completed any PE teacher training at the time of questionnaire completion. Chedzoy (2000) also reported that the perceived competence of preservice nonspecialists to teach some PE content areas increased as a result of their PE teacher education.

\section{Major Reasons Provided For and Against Feeling Confident and Competent Teaching PE}

Three inter-related factors emerged from a large selection of open-ended responses; Personal Experience and Knowledge, Qualifications, Interest and Enjoyment. Respondents did not feel confident teaching PE activities if they had minimal experience and little knowledge of the activity to be taught. Directly related to personal experience, many respondents associated feeling confident and competent in teaching PE with a high level of personal sporting ability. Moreover, respondents listed poor individual ability in sporting activities as a major inhibiting factor to feeling confident and competent when teaching PE. The relationship identified in the current study between self-perceived ability in sport and confidence teaching PE has been previously established to some extent in the literature. Respondents also related perceived confidence to level of qualification (through university or through other accredited courses). Additionally, if respondents did not personally enjoy or were not interested in a particular activity, they did not feel confident to deliver effective lessons in that area. Alternatively, respondents felt confident if they had personal experience and knowledge, relevant qualifications, or were personally interested in the particular content area. Similar results have been reported by Rolfe (2001), who found that non-specialist preservice teachers with more extensive and positive experiences in dance were more likely to be confident, personally interested, and enjoy teaching dance than those with less favourable experiences in dance. 
Approximately 75 percent of respondents indicated they were anxious teaching certain PE activities. A larger percentage of males than females had 'no safety concerns' regarding PE teaching. Gymnastics was the subject respondents would least prefer to teach, referring to safety as the major issue. Other 'least-preferred' content areas to teach included aquatics, major games, outdoor education, dance, and athletics. These findings support those of Hickey (1992) and Thompson (1996) who found that non-specialists expressed concern teaching PE, particularly gymnastics and aquatics. In the current study, a number of respondents provided examples of advanced gymnastics skills (for example, back flips and hand springs), which they believed were representative of syllabus content, to justify their preference not to teach gymnastics. However, these respondents were apparently unaware that the K-6 primary curriculum does not include these more advanced gymnastic skills. Significant implications of these type of perceptions will be addressed in the next section.

\section{Implications of the Findings}

The Nature and Influence of Personal School PE Experiences

Certainly one of the most important findings of this study was the substantial influence of personal school experiences in PE on involvement in physical activities and on perceived confidence to teach PE. Supporting Bandura's theory of social learning, results demonstrated the significance of past experiences on efficacy expectations regarding PE teaching. Individuals who recalled more negative experiences in school PE were less likely to be involved in physical activity and indicated lower levels of PE teaching confidence than those who had more favourable experiences. A positive primary and secondary school experience appears to be very important in facilitating a positive attitude to PE and physical activity and is also important in providing good models of PE teaching which may foster prospective teachers' confidence that they can also teach PE effectively. Based on these findings, the importance of personal school PE experiences (and in particular experiences in primary school) was highlighted. This importance can be promoted from two key perspectives; health and teaching. 
The importance of school PE experiences from a health perspective was represented by the strong relationships found between constructs relating to primary school PE, secondary school PE and commitment to various physical activities. The role of PE in the development of positive health behaviours has been recognised in this study. Conversely, the results have alluded to the potential negative effects of poor quality school PE experiences on some aspects of an individual's health behaviour. Accordingly, the implications for individual health should be acknowledged. It is reasonable to suggest that individuals will be more likely to be physically active, and more likely to possess positive attitudes to physical activity during childhood, and in the future, if they have experienced enjoyable and successful PE programs at school. Considering the health consequences of physical inactivity for individuals and societies, these findings have a degree of importance, and reinforce the value of quality PE programs at school.

Ultimately, PE programs should provide all children with the opportunity to enjoy their involvement in a variety of physical activities so they will feel able to participate willingly in activity throughout life. More specifically, PE programs should focus on student enjoyment and success, and provide opportunities for improving personal ability in the performance of basic motor skills, to increase the possibility of a positive PE experience. Most importantly, emphasis must be placed on encouraging the development of positive attitudes to physical activity during the primary school years, because opportunities and requirements for physical activity may decrease when students leave school. While physical activity levels may be transitory, attitudes are often more long-term.

The importance of school PE experiences from a teaching perspective was represented by the strong relationships found between personal school experiences in PE and confidence teaching PE. It seems that successful and enjoyable experiences during school PE may facilitate the development of higher levels of confidence about PE teaching for future teachers of PE. Conversely, if these experiences are less than positive, prospective and practising teachers of primary school PE may lack confidence in their ability to affect student learning in this curriculum area. As it is possible that teachers may have no or very little 'source(s) of information' about their ability to teach PE, the significance of personal school experiences in PE is strengthened as a major source of information about PE for teachers. 
Many respondents' PE experiences included programs that lacked variety and frequency of delivery, and were dominated by involvement in 'supervised' games. Essentially, PE lessons consisted of simply playing a 'game', with no emphasis on the development of fundamental motor skills and subsequently little teaching and learning occurring. It is important to consider the influence of these types of experiences on teachers' beliefs. The effects of experiencing a 'games-oriented' curriculum on the belief systems and teaching practices of specialists have been discussed in detail in the literature (refer to Crum, 1993). However, the effects of this type of experience of non-specialists are less well reported.

If a teacher has negative memories of school PE, he or she may equate these perceptions with an inability to teach PE (given the potential lack of an adequate source of information about their PE teaching ability and the established links between personal school experiences and a range of variables relating to PE teaching). Similarly, a teacher with memories of inappropriate experiences of PE (for example, a non-teaching ideology) may believe that teaching PE is unimportant or adopt and perpetuate a 'supervisory' teaching role. Subsequently, non-specialist teachers may either (a) continue to perpetuate a non-teaching ideology where they believe PE is only about 'supervised games' or (b) consider themselves incapable of teaching PE because they believe they have to be a competent performer in team sports as they associate PE only with large-sided team games.

This is an important consideration as various studies have confirmed the tendency of non-specialists to deliver inappropriate lesson content and only provided 'supervised play' in poorly organised lessons (Hardman \& Marshall, 2001). Other studies have described lessons delivered by classroom teachers as represented by students participating as an entire class in game-type activities with low engagement time in skill practice (Faucette, McKenzie, \& Patterson, 1990; Faucette \& Patterson, 1989), and some have reported the negative consequences of such programs (Faucette et al., 1990; Faucette \& Patterson, 1990). It is apparent that PE programs that are dominated by the playing of sports and major games are inappropriate for young children (Ashton, 1988) because they tend to advantage a few high ability students in a small number of activities (Armstrong \& McManus, 1994), can result in minimal success (Macfadyen, 1999), have 
negative social effects for many students (Evans \& Roberts, 1987), and do not lead to out-of-school participation in physical activities (Sallis \& McKenzie, 1991).

Another interesting finding was noted when some respondents described why they lacked confidence teaching PE. Images of more advanced sports skills negatively affected their perceptions of their ability to teach some aspects of PE. For example, some respondents did not experience gymnastics in primary school and indicated that they could not teach gymnastics because they could not perform, or were concerned about student injury when performing, a 'back flip' or a 'hand spring'. However, neither of these skills are part of the primary curriculum in Australia and these images may be based on some other experience (for example, secondary school PE or watching competitive gymnastics). Notably, the Board of Studies outlines that the gymnastics strand of the primary PE syllabus does not include Olympic or competitive gymnastics and focuses on movement exploration activities leading to participation in gymnastics. Minimal specialist equipment is required (Board of Studies, 1999, p.17). These types of images of K-6 PE teaching may operate as major inhibiting factors to the teaching of gymnastics in primary school, and extend to a number of practical content areas in PE. If memories of school PE lead to misconceptions about what and how PE lessons should be taught, those non-specialists who consider these experiences to be 'normal' practice may feel less equipped to teach PE.

Recommendations from research concerning the perpetuation of a 'game-oriented' curriculum by specialists have emphasised the important role of teacher education. Teacher educators should attempt to make students become dissatisfied and disgruntled with perpetuating their previous negative or non-teaching experiences, providing them with viable, alternative conceptions (Placek et al., 1995; Rovegno, 1993). Pajares (1992) reported that beliefs are unlikely to change unless they prove unsatisfactory and this will only occur if they are challenged. This is considered to be particularly important if prospective teachers share a familiar PE background where lessons consisted of 'supervised sport' and may not accept that other alternatives exist.

Teacher educators need to spend time assessing and discussing the personal school experiences of preservice teachers and to ensure that meaningful and appropriate learning experiences are presented. Preservice teachers need to be guided through teacher training which undertakes at least a reflection process where past 
experiences are analysed and discussed. Useful information needs to be extracted and bad images, practices, and ultimately, negative or non-teaching ideologies denounced. PE teacher educators may be required to directly challenge or complement the beliefs of preservice teachers that exist as a consequence of their personal school experiences. Specifically, PE teacher educators should recognise the importance of explaining to preservice teachers that their lack of confidence or negative attitudes may be based on memories of poor quality primary school PE that may not necessarily represent what and how PE should be taught. Similarly, their teachers may not have provided a 'best-practice' model of how to teach PE.

Preservice teachers need to understand the nature of primary school PE, and accept that they are capable of teaching various content areas and skills, particularly as it may be less advanced or of more value than they had perceived or experienced. Research in PE has demonstrated the benefits of a pedagogically appropriate PE experience in physical, social, mental and emotional domains. Explanation of these concepts, delivered via PE teacher education, should also extend to inservice teachers in the form of professional development seminars and inservice courses. Opportunities to observe and teach positive examples of PE may also dispel inaccurate and detrimental stereotypes of primary school PE.

Based on Bandura’s social learning theory, and in any attempt to influence the future teaching behaviour and decisions of teachers about PE, teacher educators would need to encourage preservice and inservice teachers to attain a certain level of mastery expectation, experience, and understanding regarding PE teaching. Biographies may need to be deconstructed and values and attitudes examined using a range of teaching strategies including reflection sessions, group work, values clarification activities, portfolios etc. Extending and applying the theory of social learning to teacher education course decisions, process, and practice may positively influence the PE teaching behaviour of primary school teachers. Opportunities for successful early experiences teaching PE should be provided through progressive exposure to more challenging and complex PE teaching tasks during preservice education. Courses should acknowledge the importance of the four major sources of information and consider the following suggestions:

\section{Insert Table 4}


Research has provided some developing evidence of the benefits of attempts to increase non-specialist teachers' mastery expectations through involvement in innovative preservice and inservice training courses that include observing and teaching PE lessons (Clarke \& Hubball, 2001; Faucette, Nugent, Sallis, \& McKenzie, 2002; Xiang et al., 2002). Effective courses should entail observation, feedback, and teaching opportunities in PE. Faucette et al. (2002) has recently shown that classroom teachers spoke of the value of watching a specialist teacher teach PE during inservice courses. Xiang et al. (2002) found that teaching PE in elementary school and observing PE classes were the two most important components affecting preservice teachers' beliefs about PE. Teacher educators need to realise that preservice teachers may not have the opportunity to teach PE and that PE teacher training courses need to incorporate a teaching component. Overall, the roles of schools and institutions may need to be made more explicit via improved communication to ensure PE is taught and supported on student teaching placements. This may be difficult, given various institutional politics but should be recognised as an important aim of any effective PE teacher education degree. Only by increasing the amount of PE teaching and/or observation experiences, will preservice teachers become more familiar with the 'realities' of teaching the K-6 syllabus, and feel more empowered to teach worthwhile PE programs.

\section{Future Research}

Because searching for an adequate model may capitalise on chance factors in the data, the fit of the measurement models and multilevel model should be cross-validated on a new and more comprehensive sample. For example, as the preservice cohort in this study was from one university only, the levels of analysis could be extended to incorporate further levels, such as different universities in the state. Additionally, longitudinal studies across teacher preparation programs need to be conducted to examine the development and resistance to change of PE teaching confidence for primary undergraduates. The effectiveness of intervention strategies to improve levels of confidence relating to PE teaching should be investigated. Furthermore, as personal school experiences seem to influence teaching ideologies, more research needs to be directed into the PE experiences of non-specialists and the ways in which these influence teaching practice. 


\section{Conclusion}

This study has demonstrated the powerful influence of personal school experiences in PE on teachers' perceptions of their ability to teach PE. This is an important finding particularly considering the nature of the PE lessons many preservice and inservice teachers have experienced. To prevent the perpetuation of a nonteaching ideology or the decision by many teachers to avoid teaching PE, teacher educators must look to incorporate biographical analysis and opportunities for PE teaching as part of preservice courses. Teacher educators who determine PE programs in teacher training occupy one of the most important positions relating to primary PE. Teacher educators can facilitate improvement in perspectives towards teaching PE by critically reflecting on the experiences of preservice teachers. Teacher educators may use this information to design appropriate courses incorporating meaningful learning experiences. Strategies employed at the tertiary level, such as increased opportunities to improve mastery expectations, should be complemented with regular and ongoing professional development for all classroom teachers.

\section{References}

Allison, P. C., Pissanos, B. W., \& Sakola, S. P. (1990). Physical education revisited - The Institutional Biographies of Preservice Classroom Teachers. Journal of Physical Education, Recreation And Dance, 61(5), 76-79.

Anderson, J.C., \& Gerbing, D.W. (1988). Structural equation modeling in practice: A review and recommended two-step approach. Psychological Bulletin, 103(3), 411-423.

Armstrong, N., \& McManus, A. (1994). Children's fitness and physical activity - A challenge for physical education. British Journal of Physical Education, 25(1), 20-26.

Arnold, C.L. (1992). An introduction to hierarchical linear models. Measurement and Evaluation in Counseling and Development, 25(2), 58-90.

Ashton, J. (1988). Children and heavy training. Sportsview, August 25, 25-26.

Australian Council for Health Physical Education and Recreation Teacher Training Working Party. (1997). Physical education teacher education in Victorian universities 1997. Melbourne: ACHPER (Victorian Branch).

Bandura, A. (1977). Self-efficacy: Toward a unifying theory of behavioral change. Psychological Review, 84(2), 191-215.

Bandura, A. (1986). Social foundations of thought and action: A social cognitive theory. Englewood Cliffs, NJ: Prentice-Hall.

Belka, D.E., Lawson, H.A., \& Cross-Lipnickey, S.C. (1991). An exploratory study of undergraduate recruitment into several major programs at one university. Journal of Teaching in Physical Education, 10(3), 286-306.

Board of Studies. (1999). Personal development, health and physical education K-6: Principals’ package. Available from the Board of Studies NSW K-6 Web site, http://www.bosnsw-k6.nsw.edu.au/pdhpe/pdhpe_index.html

Bollen, K.A. (1989). Structural equations with latent variables. New York: Wiley.

Bollen, K.A., \& Long J.S. (1993). Introduction. In K.A. Bollen \& J.S. Long (Eds.), Testing structural equation models (pp. 1-9). Thousand Oaks, CA: Sage. 
Bryk, A.S., \& Raudenbush, S.W. (1992). Hierarchical linear models: Applications and data analysis methods. Newbury Park, CA: Sage.

Carney, C., \& Chedzoy, S. (1998). Primary student teacher prior experiences and their relationship to estimated competence to teach the national curriculum for physical education. Sport, Education and Society, 3(1), 19-36.

Chedzoy, S. (2000). Students' perceived competence to teach physical education to children aged 7 to 11 years in England. European Journal of Physical Education, 5(1), 104-127.

Clarke, A., \& Hubball, H. (2001). Physical education methods course as an immersion experience in an elementary school setting. Avante, 7(2), 11-27.

Clayton, L.B. (1999). Preservice elementary classroom teachers' perceptions of past movement experiences: Physical education experiences compared to recreation or athletics experiences [Meeting abstract]. Research Quarterly for Exercise and Sport, 70(Suppl. 1, March), A82.

Cliff, N. (1983). Some cautions concerning the application of causal modeling methods. Multivariate Behavioral Research, 18(1), 115-126.

Crum, B.J. (1993). Conventional thought and practice in physical education: Problems of teaching and implications for change. Quest, 45, 339-356.

Crum, B. (1990). Shifts in professional conceptions of prospective physical education teachers under the influence of preservice professional training. In R. Telama, L. Laakso, M. Piéron, I. Ruoppila, \& V. Vihko (Eds.), Physical education and life-long physical activity. The proceedings of the Jyväskylä sport congress: Movement and sport - a challenge for life-long learning (pp. 286-294). AIESEP World Convention, Finland, June 17-22, 1989: University of Jyväskylä.

Curtner-Smith, M.D. (1999). The more things change the more they stay the same: Factors influencing teachers' interpretations and delivery of national curriculum physical education. Sport, Education and Society, 4(1), 75-97.

DeCorby, K., Halas, J., Dixon, S., Wintrup, L., \& Janzen, H. (2005). Classroom Teachers and the Challenges of Delivering Quality Physical Education. The Journal of Educational Research, 98(4), 208-220.

Dewar, A.M, \& Lawson, H.A. (1984). The subjective warrant and recruitment into physical education. Quest, 36(1), 15-25.

Doolittle, S.A., Dodds, P., \& Placek, J.H. (1993). Persistence of beliefs about teaching during formal training of preservice teachers. Journal of Teaching in Physical Education, 12(4), 355-365.

Draper, D. (1995). Inference and hierarchical modeling in the social sciences. Journal of Educational and Behavioral Statistics, 20(2), 115-147.

Evans, J., \& Roberts, G.C. (1987). Physical competence and the development of children's peer relations. Quest, 39(1), 23-35.

Faucette, N., McKenzie, T.L., \& Patterson, P. (1990). Descriptive analysis of nonspecialist elementary physical education teachers' curricular choices and class organization. Journal of Teaching in Physical Education, 9(4), 284-293.

Faucette, N., Nugent, P., Sallis, J.F., \& McKenzie, T.L. (2002). "I'd rather chew on aluminium foil.” Overcoming classroom teachers' resistance to teaching physical education. Journal of Teaching in Physical Education, 21(3), 287-308.

Faucette, N., \& Patterson, P. (1989). Classroom teachers and physical education: What they are doing and how they feel about it. Education, 110(1), 108-114.

Faucette, N., \& Patterson, P. (1990). Comparing teaching behaviours and student activity levels in classes taught by P.E. specialists versus nonspecialists. Journal of Teaching in Physical Education, 9(2), 106-114.

Goldstein, H. (1995). Multilevel statistical models (2nd ed.). London: Edward Arnold.

Graham, G. (1991). An Overview of TECPEP. Journal of Teaching in Physical Education, 10(4), 323-334.

Haag, G.G. (1992). Causal modeling in sport science: Theoretical background and problems related to practical computer applications. In G. Tenenbaum, T. Raz-Liebermann, \& Z. Artzi (Eds.), Proceedings of the international conference on computer applications in sport and physical education (pp. 160-171). Netanya, Wingate Institute: The Zinman College.

Hair, J.F., Jr., Anderson, R.E., Tatham, R.L., \& Black, W.C. (1995). Multivariate data analysis with readings (4th ed.). Englewood Cliffs, NJ: Prentice Hall.

Hardman, K., \& Marshall, J.J. (2001). World-wide survey on the state and status of physical education in schools. In Doll-Tepper, G. (Ed.), Proceedings of the World Summit on Physical Education, Berlin $3^{\text {rd }}-5^{\text {th }}$ November, 1999 (pp. 15-37). Berlin:International Council of Sport Science and Physical Education. 
Hickey, C. (1992). Physical education in Victorian primary schools: A review of current provision. The ACHPER National Journal, 138, 18-23.

Howarth, K. (1987). Initial training in primary physical education - no substitute for teamwork. British Journal of Physical Education, 18(4), 152-153.

Hox, J.J. (1995). Applied multilevel analysis. Amsterdam: TT-Publikaties.

Hu, L., \& Bentler, P.M. (1995). Evaluating model fit. In R.H. Hoyle (Ed.), Structural equation modeling: Concepts, issues, and applications (pp. 76-99). Thousand Oaks, CA: Sage.

Jarrett, O.S. (1999). Science interest and confidence among preservice elementary teachers. Journal of Elementary Science Education, 11(1), 47-57.

Jöreskog, K.G., \& Sörbom, D. (1993). LISREL 8: User's Reference Guide. Chicago: Scientific Software International.

Keating, X.D., Silverman, S., \& Kulinna, P.H. (2002). Preservice physical education teacher attitudes toward fitness tests and the factors influencing their attitudes. Journal of Teaching in Physical Education, 21(2), 193-207.

Kelloway, K.E. (1998). Using LISREL for structural equation modeling: A researcher's guide. Thousand Oaks, CA: Sage.

Kirk, D. (1989). Daily physical education research: A review and a critique. Physical Education Review, 12(1), 21-30.

Kirk, D., Colquhoun, D., \& Gore, J. (1988). Generalists, specialists and daily physical education in Queensland. The ACHPER National Journal, 122, 7-9: 36.

Lavee, Y. (1988). Linear structural relationships (LISREL) in family research. Journal of Marriage and the Family, 50, 937-948.

Lawson, H.A. (1986). Occupational socialization and the design of teacher education programs. Journal of Teaching in Physical Education, 5(2), 107-116.

Lawson, H.A. (1983a). Paradigms for research on teaching and teachers. In T.J. Templin \& J.K. Olson (Eds.), Teaching in physical education (pp. 339-358). Champaign, IL: Human Kinetics.

Lawson, H.A. (1983b). Toward a model of teacher socialization in physical education: The subjective warrant, recruitment and teacher education (Pt. 1). Journal of Teaching in Physical Education, 2(3), 3-16.

Li, F., Duncan, T.E., Harmer, P., Acock, A., \& Stoolmiller, M. (1998). Analyzing measurement models of latent variables through multilevel confirmatory factor analysis and hierarchical linear modelling approaches. Structural Equation Modeling, 5(3), 294-306.

Locke, L. (1984). Research on teaching teachers: Where are we now? [Monograph 2], Journal of Teaching in Physical Education, 2, 63-85.

Loehlin, J.C. (1992) Latent variable models : An introduction to factor, path, and structural analysis ( $2^{\text {nd }}$ ed.). Hillsdale, NJ: Lawrence Erlbaum Associates.

Macfadyen, T. (1999). An analysis of the influence of secondary school physical education on young people's attitudestowards physical activity. The Bulletin of Physical Education, 35(3), 157-171.

MacKendrick, M. (1996). Active living + quality daily physical education = the perfect solution. The Canadian Association for Health, Physical Education, Recreation and Dance Journal, 62(1), 2.

Moore, D., Webb, P., \& Dickson, S. (1997). Perceptions of preservice primary teachers in teaching personal development, health and physical education. In J.J. Walkuski, S.C. Wright, \& S.K.S. Tan (Eds.), Proceedings of the World Conference on Teaching, Coaching and Fitness Needs in Physical Education and the Sport Sciences (pp. 144-152). Singapore: AIESEP.

Morgan, P.J. \& Bourke, S.F. (2005). An investigation of preservice and primary school teachers' perspectives of PE teaching confidence and PE teacher education. ACHPER Healthy Lifestyles Journal 52(1), 7-13.

Morgan, P.J. \& Bourke, S.F. (2004, November). "I know it's important but I'd rather teach something else!": An investigation into generalist teachers' perceptions of physical education in the primary school curriculum. Paper presented at the Australian Association for Research in Education Conference, Melbourne, Victoria.

Osborne, J.W. (2000). Advantages of hierarchical linear modelling Practical Assessment, Research \& Evaluation, 7(1), Retrieved October 13, 2001, from http://www.ericae.net/pare/getvn.asp?v=7\&n=1

Pajares, M.F. (1992). Teachers' beliefs and educational research: Cleaning up a messy construct. Review of Educational Research, 62(3), 307-332.

Pang, N.S.K. (1996). School values and teachers' feelings: A LISREL model. Journal of Educational Administration, 34(2), 64-83. 
Pedhazur, E.J. (1997). Multiple regression in behavioral research: Explanation and prediction (3rd ed.). Orlando, FL: Harcourt Brace College.

Placek, J.H., \& Dodds, P. (1988). A critical incident study of preservice teachers' beliefs about teaching success and nonsuccess. Research Quarterly for Exercise and Sport, 59(4), 351-358.

Placek, J.H., Dodds, P., Doolittle, S.A., Portman, P.A., Ratliffe, T.A., \& Pinkham, K.M. (1995). Teaching recruits' physical education backgrounds and beliefs about purposes for their subject matter. Journal of Teaching in Physical Education, 14(3), 246-261.

Portman, P.A. (1996). Preservice elementary education majors beliefs about their elementary physical education classes (Pt. 1). Indiana Association for Health, Physical Education, Recreation and Dance Journal, 25(2) 25-28.

Rasbash, J., Browne, W., Goldstein, H., Yang, M., Plewis, I., Healy, M., et al. (2000). A user's guide to MlwiN (version 2.1a). Multilevel Models Project, Institute of Education: University of London.

Rolfe, L. (2001). The factors which influence primary student teachers' confidence to teach dance. European Physical Education Review, 7(2), 157-175.

Rovegno, I. (1993). Content-knowledge acquisition during undergraduate teacher education: Overcoming cultural templates and learning through practice. American Educational Research Journal, 30(3), 611-642.

Russell-Bowie, D., McInerney, D.M., \& Yeung, A. (2001, December). Student teachers' perceptions of anxiety and confidence in relation to music education. Paper presented at the annual conference of the Australian Association for Research in Education, Fremantle, Western Australia.

Sallis, J.F., \& McKenzie, T.L. (1991). Physical education's role in public health. Research Quarterly for Exercise and Sport, 62(2), 124-137.

Sallis, J.F., Prochaska, J.J., Taylor, W.C., Hill, J.O., \& Geraci, J.C. (1999). Correlates of physical activity in a national sample of girls and boys in grades 4 through 12. Health Psychology, 18(4), 410-415.

Senate Standing Committee on Environment, Recreation and the Arts. (1992). Physical and Sport Education. Canberra: The Parliament of the Commonwealth of Australia.

Senate Environment, Recreation, Communications and the Arts References Committee. (1995). Arts education. Canberra: Commonwealth of Australia.

Smith, J. (1999, November). We need more males in primary teacher education! or do we? Paper presented at the annual conference of the Australian Association for Research in Education, Melbourne, Victoria.

Thompson, K. (1996). Physical education and sport in Hunter region primary schools. Unpublished doctoral dissertation, University of Newcastle, New South Wales.

Tinning, R., \& Hawkins, K. (1988). Montaville revisited: A daily physical education program four years on. The ACHPER National Journal, 121, 24-29.

Walkley, J. (1992). The preparation of teachers of primary school physical education in Victoria: A cause for concern. ACHPER, Victorian Branch: ACHPER.

Webb, P., Moore, D., Gray, T., \& Jessup, S. (1993). Analysis and evaluation of primary physical education courses in tertiary institutions. In Reaching for the Top: Proceedings of the $19^{\text {th }}$ ACHPER National/International BiennialConference Health and Physical Education Volume 1, Darwin: ACHPER.

Xiang, P., Lowy, S., \& McBride, R. (2002). The impact of a field-based elementary physical education methods course on preservice classroom teachers' beliefs. Journal of Teaching in Physical Education, 21(2), 145-161.

Zhu, W. (1997). A multilevel analysis of school factors associated with health-related fitness. Quarterly for Exercise and Sport, 68(2), 125-135.

Research 
Table 1

\section{Description of Construct Development using Fitted One-factor Congeneric Measurement Models}

\begin{tabular}{|c|c|c|c|c|c|c|c|c|c|c|}
\hline $\begin{array}{l}\text { Initial } \\
\text { Source/Description }\end{array}$ & CONSTRUCT & $\begin{array}{l}\text { Multivariate Construct } \\
\text { Description }\end{array}$ & $\begin{array}{l}\text { Item/Question } \\
\text { Example }\end{array}$ & $\chi^{2}$ & $\mathrm{p}$ & $d f$ & GFI & RMSEA & RMR & $\rho \xi_{x}$ \\
\hline \multirow{2}{*}{$\begin{array}{l}\text { Personal School } \\
\text { Experiences in } \\
\text { Primary School } \\
\text { PE } \\
\text { Two distinct factors } \\
\text { emerged from nine } \\
\text { items (six-point } \\
\text { Likert). }\end{array}$} & $\begin{array}{l}\text { Quality of } \\
\text { Primary PE } \\
\text { Program } \\
\text { (5 items) }\end{array}$ & $\begin{array}{l}\text { - Quality of teaching } \\
\text { - Frequency of } \\
\text { lessons } \\
\text { - Variety and number } \\
\text { of activities offered } \\
\text { - Skills focus of the } \\
\text { program }\end{array}$ & $\begin{array}{l}\text { 'The quality of } \\
\text { teaching I } \\
\text { received was } \\
\text { excellent' }\end{array}$ & 3.31 & 0.35 & 3 & 0.998 & 0.013 & 0.017 & 0.608 \\
\hline & $\begin{array}{l}\text { Outcome } \\
\text { Attainment in } \\
\text { Primary PE } \\
\text { (4 items) }\end{array}$ & $\begin{array}{l}\text { - Level of activity } \\
\text { - Perceived } \\
\text { competence in skill } \\
\text { performance and } \\
\text { success } \\
\text { - Perceptions of } \\
\text { enjoyment }\end{array}$ & $\begin{array}{l}\text { 'PE was } \\
\text { enjoyable in } \\
\text { primary } \\
\text { school' }\end{array}$ & 0.51 & 0.48 & 1 & 1.000 & 0.0 & 0.006 & 0.868 \\
\hline $\begin{array}{l}\text { Personal School } \\
\text { Experiences In } \\
\text { Secondary School } \\
\text { PE } \\
\text { Only one factor } \\
\text { emerged from nine } \\
\text { items (six-point } \\
\text { Likert). }\end{array}$ & $\begin{array}{l}\text { Experience in } \\
\text { Secondary PE } \\
\text { (4 items) }\end{array}$ & $\begin{array}{l}\text { - Quality of teaching } \\
\text { - Perceptions of } \\
\text { enjoyment } \\
\text { - Perceived } \\
\text { competence in skill } \\
\text { performance and } \\
\text { success }\end{array}$ & $\begin{array}{l}\text { 'I found most } \\
\text { activities I } \\
\text { participated in } \\
\text { difficult to } \\
\text { perform' }\end{array}$ & 3.40 & 0.18 & 2 & 0.999 & 0.032 & 0.011 & 0.894 \\
\hline $\begin{array}{l}\text { Included nine } \\
\text { ordinal variables } \\
\text { related to current } \\
\text { and school } \\
\text { perceptions of } \\
\text { ability in sport, type } \\
\text { of sports } \\
\text { involvement for the } \\
\text { last five years and } \\
\text { interest and } \\
\text { participation in } \\
\text { sport at school and } \\
\text { now. One factor } \\
\text { emerged. }\end{array}$ & $\begin{array}{l}\text { Commitment } \\
\text { to Sport \& } \\
\text { Physical } \\
\text { Activity } \\
\text { (4 items) }\end{array}$ & $\begin{array}{l}\text { - Current involvement } \\
\text { in sport } \\
\text { - Perceived sporting } \\
\text { ability } \\
\text { - Interest in sport } \\
\text { - Interest and } \\
\text { participation in sport } \\
\text { at school }\end{array}$ & $\begin{array}{l}\text { 'Indicate your } \\
\text { current } \\
\text { involvement } \\
\text { for each sport } \\
\text { you play } \\
\text { (representative, } \\
\text { competition, and } \\
\text { recreation)' }\end{array}$ & 2.42 & 0.30 & 2 & 0.999 & 0.018 & 0.010 & 0.896 \\
\hline
\end{tabular}

- KEY: $\chi^{2}=$ Chi-Square; $p=$ Probability; $d f$ = Degrees of freedom; GFI = Goodness-of-Fit Index; RMSEA = Root Mean Square Error of

Approximation; $R M R=$ Root Mean Square Residual; $p \xi_{x}=$ Estimate of reliability 
Table 2

Correlation Matrix for Model Variables

\begin{tabular}{|c|c|c|c|c|c|c|c|}
\hline & 1. & 2. & 3. & 4. & 5. & 6. & 7. \\
\hline \multicolumn{8}{|l|}{ 1. Gender } \\
\hline 2. Age & $\begin{array}{c}-\mathbf{0 . 1 8 9 * *} \\
(0.000)\end{array}$ & & & & & & \\
\hline 3. Quality of Primary PE & $\begin{array}{l}\mathbf{0 . 0 8 5} \\
(0.074)\end{array}$ & $\begin{array}{l}-0.063 \\
(0.188)\end{array}$ & & & & & \\
\hline 4. Outcome Attainment in Primary PE & $\begin{array}{c}-0.117^{*} \\
(0.014)\end{array}$ & $\begin{array}{l}-0.021 \\
(0.665)\end{array}$ & $\begin{array}{c}\mathbf{0 . 5 1 2}^{* *} \\
(0.000)\end{array}$ & & & & \\
\hline 5. Experience in Secondary PE & $\begin{array}{c}-\mathbf{0 . 1 2 5} 5^{\star *} \\
(0.009)\end{array}$ & $\begin{array}{c}\mathbf{0 . 0 2 2} \\
(0.653)\end{array}$ & 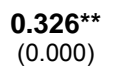 & $\begin{array}{c}\mathbf{0 . 6 7 7 ^ { * * }} \\
(0.000)\end{array}$ & & & \\
\hline 6. Commitment to Sport \& PA & $\begin{array}{c}-0.308^{\star *} \\
(0.000)\end{array}$ & $\begin{array}{l}-0.046 \\
(0.336)\end{array}$ & $\begin{array}{c}\mathbf{0 . 2 0 1 * *} \\
(0.000)\end{array}$ & $\begin{array}{c}\mathbf{0 . 5 1 2 * *} \\
(0.000)\end{array}$ & 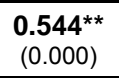 & & \\
\hline 7. Confidence Teaching PE & $\begin{array}{l}-0.031 \\
(0.517)\end{array}$ & $\begin{array}{c}-0.112^{*} \\
(0.019)\end{array}$ & $\begin{array}{c}\mathbf{0 . 1 6 6 * *} \\
(0.000)\end{array}$ & 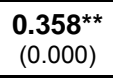 & $\begin{array}{c}\mathbf{0 . 3 9 0 * *} \\
(0.000)\end{array}$ & $\begin{array}{c}\mathbf{0 . 4 5 9 * *} \\
(0.000)\end{array}$ & \\
\hline $\begin{array}{c}\text { Mean } \\
\text { (Standard Deviation) } \\
\text { Range }\end{array}$ & $\begin{array}{c}1.85 \\
(0.36) \\
1-2\end{array}$ & $\begin{array}{c}2.10 \\
(1.23) \\
1-8\end{array}$ & $\begin{array}{c}\mathbf{4 . 4 5} \\
(0.945) \\
1-6\end{array}$ & $\begin{array}{c}4.40 \\
(1.14) \\
1-6\end{array}$ & $\begin{array}{c}3.97 \\
(1.32) \\
1-6\end{array}$ & $\begin{array}{l}3.30 \\
(1.18) \\
0-6.5\end{array}$ & $\begin{array}{c}4.22 \\
(0.79) \\
1-6\end{array}$ \\
\hline
\end{tabular}

a Pearson correlation and 2-tailed significance in brackets

$b \quad * \quad$ Correlation is significant at the 0.05 level (2-tailed)

** Correlation is significant at the 0.01 level (2-tailed)

c $\quad P A=$ Physical Activity: Gender code: Male $=1$, Female $=2$. 
Table 3 Null and Fitted Standardised Model for Personal School PE Experience and Commitment to Sport and Physical Activity and Confidence Teaching PE Categories as Response Variables

\begin{tabular}{|c|c|c|c|c|c|c|c|}
\hline \multicolumn{3}{|c|}{$\begin{array}{l}\text { Personal School Experiences, Commitment to } \\
\text { Sport and PA and Confidence Teaching PE } \\
\qquad(n=439)\end{array}$} & $\begin{array}{l}\text { Quality of } \\
\text { Primary PE } \\
\text { Program }\end{array}$ & $\begin{array}{l}\text { Outcome } \\
\text { Attainment } \\
\text { in Primary } \\
\quad \text { PE }\end{array}$ & $\begin{array}{l}\text { Experience } \\
\text { in } \\
\text { Secondary } \\
\quad \text { PE }\end{array}$ & $\begin{array}{l}\text { Commitment } \\
\text { to Sport \& } \\
\text { PA }\end{array}$ & $\begin{array}{l}\text { Confidence } \\
\text { Teaching PE }\end{array}$ \\
\hline \multicolumn{3}{|r|}{$\begin{array}{l}\text { Standardised Regression Coefficient } \\
\text { (Standard Error) }\end{array}$} & $\begin{array}{c}\beta \\
\left(\mathrm{SE}_{\beta}\right) \\
\end{array}$ & $\begin{array}{c}\beta \\
\left(\mathrm{SE}_{\beta}\right) \\
\end{array}$ & $\begin{array}{c}\beta \\
\left(\mathrm{SE}_{\beta}\right) \\
\end{array}$ & $\begin{array}{c}\beta \\
\left(\mathrm{SE}_{\beta}\right)\end{array}$ & $\begin{array}{c}\beta \\
\left(\mathrm{SE}_{\beta}\right)\end{array}$ \\
\hline \multirow{4}{*}{ 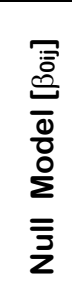 } & $\begin{array}{c}\text { Fixed } \\
\text { Part }\end{array}$ & Constant $\left[\beta_{0}\right]$ & $\begin{array}{l}-0.005 \\
(0.069) \\
\end{array}$ & $\begin{array}{c}0.000 \\
(0.048) \\
\end{array}$ & $\begin{array}{c}0.019 \\
(0.076) \\
\end{array}$ & $\begin{array}{c}0.000 \\
(0.048) \\
\end{array}$ & $\begin{array}{c}0.016 \\
(0.121) \\
\end{array}$ \\
\hline & \multirow{3}{*}{ 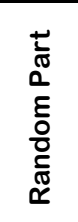 } & - $\left[\mathrm{u}_{0 \mathrm{j}}\right] \sim \mathrm{N}\left(0, \Omega_{\mathrm{u}}\right): \Omega_{\mathrm{u}}=\left[\sigma_{\mathrm{u} 0}^{2}\right]$ Level 2 & $\begin{array}{c}0.009 \\
(0.013)\end{array}$ & $\begin{array}{l}0.000 \\
(0.000)\end{array}$ & $\begin{array}{c}0.013 \\
(0.016)\end{array}$ & $\begin{array}{c}0.000 \\
(0.000)\end{array}$ & $\begin{array}{c}0.049 \\
(0.042)\end{array}$ \\
\hline & & - $\left[\mathrm{e}_{0 \mathrm{ij}}\right] \sim \mathrm{N}\left(0, \Omega_{\mathrm{e}}\right): \Omega_{\mathrm{e}}=\left[\sigma_{\mathrm{e} 0}^{2}\right]$ Level 1 & $\begin{array}{l}0.988 \\
(0.067)\end{array}$ & $\begin{array}{l}0.998 \\
(0.067)\end{array}$ & $\begin{array}{l}0.984 \\
(0.067)\end{array}$ & $\begin{array}{l}0.998 \\
(0.067)\end{array}$ & $\begin{array}{c}0.940 \\
(0.064)\end{array}$ \\
\hline & & Intra-cohort correlation coefficient $(\rho)$ & 0.009 & 0.000 & 0.013 & 0.000 & 0.050 \\
\hline \multirow{13}{*}{ 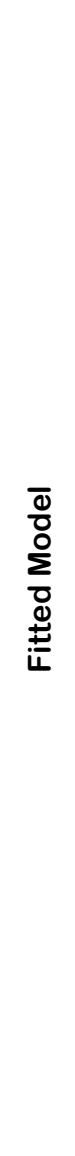 } & \multirow{10}{*}{ 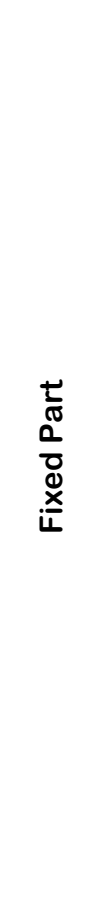 } & $\begin{array}{l}\text { Level } 1 \\
\text { Constant }\left[\beta_{0}\right]\end{array}$ & & $\begin{array}{c}0.000 \\
(0.040)\end{array}$ & $\begin{array}{c}0.000 \\
(0.035)\end{array}$ & $\begin{array}{l}0.042 \\
(0.094)\end{array}$ & $\begin{array}{l}0.000 \\
(0.040)\end{array}$ \\
\hline & & - Commitment to Sport and PA & NI & NI & $\mathrm{NI}$ & $\mathrm{NI}$ & $\begin{array}{c}0.292 \\
(0.048)\end{array}$ \\
\hline & & - Experience in Secondary PE & $N I$ & $N I$ & $\mathrm{NI}$ & $\begin{array}{c}0.348 \\
(0.049)\end{array}$ & $\begin{array}{c}0.232 \\
(0.048)\end{array}$ \\
\hline & & - Outcome Attainment in Primary PE & $N I$ & $N I$ & $\begin{array}{c}0.677 \\
(0.035)\end{array}$ & $\begin{array}{c}0.244 \\
(0.050)\end{array}$ & - \\
\hline & & - Quality of Primary PE Program & $N I$ & $\begin{array}{c}0.526 \\
(0.040)\end{array}$ & - & - & - \\
\hline & & - Gender & - & $\begin{array}{l}-0.162 \\
(0.040)\end{array}$ & - & $\begin{array}{l}-0.257 \\
(0.037)\end{array}$ & - \\
\hline & & $\begin{array}{l}-\quad \text { Age } \\
\text { Level } 2\end{array}$ & - & - & - & $\begin{array}{l}-0.151 \\
(0.040)\end{array}$ & $\begin{array}{l}-0.165 \\
(0.041)\end{array}$ \\
\hline & & - $2^{\text {nd }}$ Year University & $N I$ & $N I$ & $\mathrm{NI}$ & $\mathrm{NI}$ & $\begin{array}{l}-0.248 \\
(0.042)\end{array}$ \\
\hline & & - $3^{\text {rd }}$ Year University & $N I$ & $N I$ & $N I$ & $\mathrm{NI}$ & - \\
\hline & & - $4^{\text {th }}$ Year University & $\mathrm{NI}$ & NI & NI & NI & - \\
\hline & \multirow{3}{*}{ 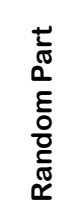 } & - $\left[\mathrm{u}_{0 \mathrm{j}}\right] \sim \mathrm{N}\left(0, \Omega_{\mathrm{u}}\right): \Omega_{\mathrm{u}}=\left[\sigma_{\mathrm{u} 0}^{2}\right]$ & - & $\begin{array}{c}0.000 \\
(0.000)\end{array}$ & $\begin{array}{c}0.029 \\
(0.025)\end{array}$ & $\begin{array}{l}0.000 \\
(0.000)\end{array}$ & $\begin{array}{l}0.000 \\
(0.000)\end{array}$ \\
\hline & & - $\left[\mathrm{e}_{0 \mathrm{ij}}\right] \sim \mathrm{N}\left(0, \Omega_{\mathrm{e}}\right): \Omega_{\mathrm{e}}=\left[\sigma_{\mathrm{e} 0}^{2}\right]$ & - & $\begin{array}{l}0.710 \\
(0.048)\end{array}$ & $\begin{array}{l}0.577 \\
(0.039)\end{array}$ & $\begin{array}{c}0.541 \\
(0.037)\end{array}$ & $\begin{array}{c}0.694 \\
(0.047)\end{array}$ \\
\hline & & Intra-cohort correlation coefficient $(\rho)$ & $\mathrm{N} / \mathrm{A}$ & 0.000 & 0.048 & 0.000 & 0.000 \\
\hline \multicolumn{3}{|c|}{$\begin{array}{l}\text { - Omitted category for dummy variable }=\text { Inservice teachers } \\
\text { - } N I=\text { Not included in sub-model analysis } \\
\text { - } N / A=\text { Not Applicable }\end{array}$} & $R^{2}=N / A$ & $R^{2}=0.289$ & $R^{2}=0.458$ & $R^{2}=0.392$ & $R^{2}=0.298$ \\
\hline
\end{tabular}


Table 4

Strategies to Increase Mastery Expectations of Non-specialist Preservice Teachers of PE

\begin{tabular}{|c|c|}
\hline $\begin{array}{l}\text { Sources of } \\
\text { information }\end{array}$ & Strategy \\
\hline $\begin{array}{c}\text { Performance } \\
\text { Accomplishments }\end{array}$ & $\begin{array}{l}\text { The absence of teaching opportunities during practicums inhibits the development of effective } \\
\text { teaching skills. Opportunities for successul early experiences teaching PE should be provided } \\
\text { through progressive exposure to more challenging and complex PE teaching tasks during preservice } \\
\text { education. If preservice teachers have early successful experiences in teaching PE, Bandura's (1977, } \\
\text { 1986) theories would suggest that they would develop higher levels of confidence in their ability to } \\
\text { affect student learning, thus motivating them to persist with the task. Learning experiences such as } \\
\text { role play opportunities and peer teaching tasks should be incorporated into courses, followed by } \\
\text { 'micro' teaching experiences (where preservice teachers only teach small groups of } 6-8 \text { children) and } \\
\text { finally, adequately supported 'whole class' teaching. }\end{array}$ \\
\hline $\begin{array}{l}\text { Vicarious } \\
\text { Experience }\end{array}$ & $\begin{array}{l}\text { Preservice teachers can benefit from observing experienced teachers or credible role models teach } \\
\text { 'successful' lessons (via video, visits to schools, or on practicum) as part of course content. }\end{array}$ \\
\hline Verbal Persuasion & $\begin{array}{l}\text { Teacher educators need to discuss and critically reflect upon past experiences with preservice } \\
\text { teachers and, if necessary, convince them that they can cope successfully with primary school PE } \\
\text { teaching and highlight positive achievements. Preservice teachers need to have explained that they } \\
\text { may have experienced poor quality PE programs at school and this may have a significant adverse } \\
\text { influence on how they feel about PE and their future teaching decisions. Teachers need to be } \\
\text { convinced that quality PE programs can lead to the attainment of an array of favourable outcomes for } \\
\text { students. }\end{array}$ \\
\hline Physiological States & $\begin{array}{l}\text { Preservice teachers need to be encouraged to teach PE in primary schools in order to develop a } \\
\text { greater understanding of the nature of the syllabus content and to overcome any existing negative or } \\
\text { inappropriate images. This may assist the development of coping skills by reducing the emotional } \\
\text { arousal of previous adversities. }\end{array}$ \\
\hline
\end{tabular}




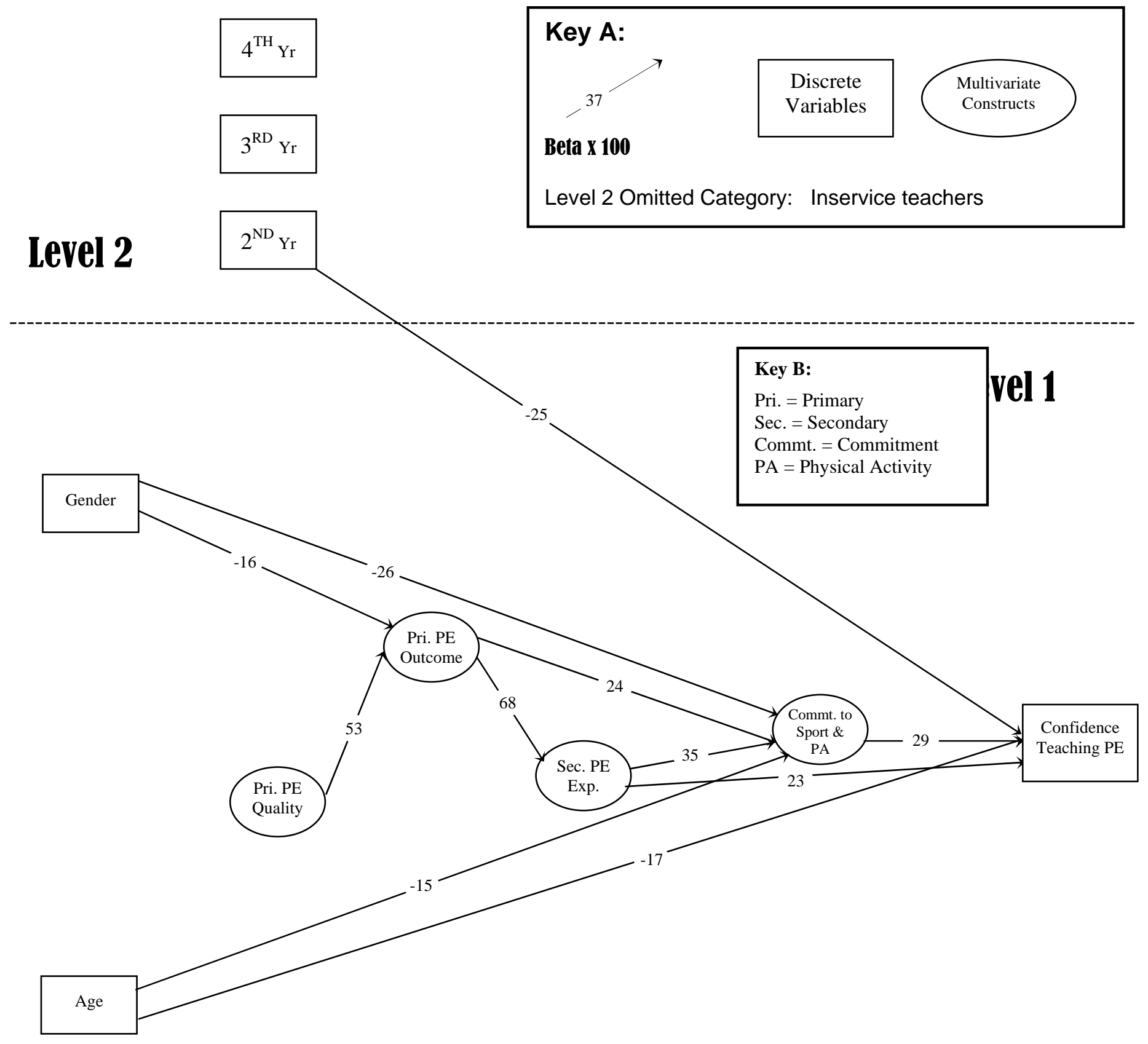

Figure 1 Standardised Multilevel Model 